\title{
Senior Secondary School Children's Understanding Of Plant Nutrition
}

\author{
Modise Mosothwane, University of Botswana, Botswana
}

\begin{abstract}
The purpose of this study was to assess children's understanding of plant nutrition. The research was done on a sample of secondary school pupils in the age range of 16 to 19 years in two senior secondary schools in Botswana. The sample contained 137 senior secondary pupils all in their final year of study. These children were above average ability. The children were given a test on plant nutrition composed of two parts namely forced and free responses which were based on the Botswana senior secondary school biology syllabus.

After the administration of the test to the pupils, interviews were conducted to give children the opportunity to explain their answers. The majority of children experienced little difficulty in providing accepted ideas about plant nutrition. However, analysis of children's responses showed that mistakes were often made in the process of where plants make food rather than in the process of how plants make food. In conclusion, suggestions and recommendations were made with the hope that they would help teachers teach plant nutrition in a meaningful way.
\end{abstract}

Keywords: nutrition; nutrients; plant nutrition

\section{INTRODUCTION}

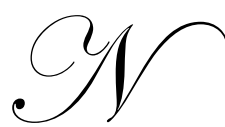

utrients are essential to the life of both plants and animals on earth (Bell \& Brook, 1984). Nutrients are chemical elements or compounds used in an organism's metabolism, that is a series of processes taking place in which food is converted into energy and other products needed for survival. However, ways in which plants and animals obtain their nutrients are different. Plants make their own food mainly starches and glucose (autotrophs) while animals use what plants manufactured as their food (heterotrophs). Plants nutrition is an important concept which should be understood by all children in senior secondary schools. Since Botswana is predominantly a farming country, it is important that children should have a clear understanding of plant nutrition and should be able to detect symptoms of nutrient deficiency exhibited by plants. Furthermore, senior secondary school children should be able to apply the right amounts of nutrients in the correct proportion.

Plant nutrition is the study of chemical elements required for plant growth. Countries worldwide have included plant nutrition in their secondary school biology syllabuses to lay a strong foundation for studying plant physiology and ecology at higher levels of education. In Botswana, science is compulsory and it is taken by all children in senior secondary schools. These children study plant nutrition in biological sciences; however, those who take biology as a pure science study plant nutrition in depth (Republic of Botswana, 2000).

In Botswana, studies on children's conceptions of biological science concepts are underrepresented (Ramorogo, 1995). In Britain and the USA voluminous studies have been conducted on children's conceptions of biological science concepts (Wandersee, Mintzes and Novak, 1994; Mintzes, Trowbridge, Arnaudin \& Wandersee, 1991; Bell and Brook, 1984). Detailed studies on children's understanding of plant nutrition have been conducted in Britain (Bell and Brook, 1984), but no studies have been conducted on children's conceptions of plant nutrition in Botswana. Therefore this small scale study will provide essential information on children's conception of plant nutrition. Children's ideas of science have been reported to have helped teachers teach science concepts in a meaningful and effective way (Driver, 1989). 
According to McClelland (1985), meaningful learning occurs when learners are able to relate new concepts to previously learned ones. Using previous knowledge to learn new concepts would help children to experience little or no cognitive dissonance. McClelland has also reported that when science is taught without using children's ideas, concepts taught are more likely to be unrelated, to be poorly understood and to be quickly forgotten. If Batswana children's ideas about plant nutrition are known, teachers will concentrate on those ideas that most children do not understand. Furthermore, teachers will also have to re-conceptualize the way they have been teaching science

Research studies in both Britain and the USA suggest that children recognize plant nutrients as essential ingredients required by plants for growth and development (Wandersee, Mintzes and Novak, 1994; Mintzes, Trowbridge, Arnaudin, Wandersee, 1991; Bell and Brook, 1984). These studies reported that most secondary school pupils associated nutrients more with animals than with plants. This confirms the widely held perspective that children's ideas are based on observable features (Baxter, 1989) Children therefore conceptualize nutrition as food that can be seen with naked eyes. Plant nutrients are divided into two categories, namely non-minerals and minerals. Mineral nutrients are also divided into two categories, namely, micronutrients and macronutrients. For non-mineral nutrients, plants get carbon, hydrogen and oxygen from air and water. With the help of the sun, plants make starches and sugars. However, plants get mineral nutrients from the soil. Plants require macronutrients in large amounts because they use them for growth and survival, especially primary macronutrients.

Since children are taught in biology lessons that micronutrients are required in small amounts by plants, , the perception that plant nutrients are too small to be seen with an ordinary eye seems to be generally accepted and well established. Apparently students who are doing agriculture tend to understand nutrients better since they use fertilizers to increase nutrients in soil. However, students still do not have mental image of plant nutrition since they consider nutrition as something that can be seen and be eaten. In a study conducted by Bell and Brook, (1984), children associated plant nutrition with food that animals eat and contradictions were evident in the way children interpret nutrition. It means that mechanisms of plant nutrition are not well understood by children. Many children were found to hold on to their own conceptions even after considerable instruction to help them understand biological explanations of plant nutrition. Resnick (1983) noted that children come to science lessons with extensive theories about the real world events, but warned that even after instruction learners still resort to their prior theories. This justifies the widely held view that children come to school with their own ideas not as blank slates on which to inscribe knowledge (Harlen, 1993).

In view of the above observations, two things emerge, firstly there should be a shift in paradigm in the teaching of scientific concepts, from that of delivering content into learners' cognitive structures to that of using learners' ideas to make learning more meaningful and relevant, and secondly failing to use children's ideas in teaching scientific concepts could interfere with learning. It is therefore important that teachers use children's ideas as a resource for teaching science concepts. It has been established that children's preconceptions (ideas held before instruction) pose strong barriers to understanding science concepts (Clement, Brown and Zietsman, 1989). Although researchers agree that children's ideas may be in conflict with convectional science and as a result could deter further learning of science concepts, Clement, Brown and Zietsman, (1989) argue that not all preconceptions are misconceptions. They contend "- although many preconceptions are detrimental to learning, there may be other preconceptions that are largely in agreement with accepted physical theory (p.554). Since the preconceptions are embedded within children's conceptual maps, it is important that teachers teach science concepts using ideas which are in line with conventional science. Such a move will help to bring in conceptual change which is the goal of teaching science. Teaching science for conceptual change is reported to have enhanced students' conceptual understanding ( Smith, 1989)

Clement, Brown and Zietsman (1989) hold the view that students' preconceptions can be used as anchoring conceptions since they will anchor new concepts being taught. New concepts being taught will at least have somewhere to be 'hooked on'.

Clement, Brown and Zietsman (1989) contend:

While considerable research has been conducted on misconceptions in science, very little is known about anchoring conceptions. In order to develop a more systematic approach to promoting conceptual change in certain domains, it 
could be productive to identify what can be used as anchoring conceptions and what are effective bridging analogies in the domain (p, 555).

Mintze, Trowbridge, Arnaudin \& Wandersee (1991) have conducted research in biology teaching and have reported that learners construct meanings which seek to make sense of their biological surroundings. In other words, learners link what they learn in biology with what exist in their environments.

Mintzes, Trowbridge, Arnaudin \& Wandersee (1991) contend:

In so doing, they generate links between sensory information and relevant aspects of prior knowledge the meaning that learners construct are frequently at variance with those held by the scientific community and furthermore, they are often stubbornly intractable, at least when confronted by convectional instruction (p.192).

Children's conceptions are an enormously powerful tool to help teachers choose the most appropriate instructional strategy that would enhance understanding of scientific concepts. The goal of science is to promote conceptual change so that scientific literacy is enhanced. Teachers who teach for conceptual change use children's ideas to teach new science concepts and as such are considered agents of change. Solomon (1993) asserts that it can no longer be argued whether or not children have out of school notions which affect their learning of school science. Solomon asserts that children's preconceptions are largely influenced by their environments rather than by school science. She however, emphasized that convectional science could be promoted in science classes if teachers ensure that children use scientific language in their discussion. Solomon (1993) has indicated that the use of 'loose' language in science lessons by both teachers and pupils has significantly contributed to the prevalence of misconceptions exhibited by children

\section{THEORETICAL FRAMEWORK}

The theoretical framework for this study is based on Solomon's two domains of knowledge namely scientific and life-world knowledge. Every time children learn new science concepts, they first put them into their life world knowledge and see if they fit. In most cases school science tend to be at cognitive dissonance with life world knowledge.

Children's ideas are heavily influenced by Life world knowledge rather than scientific knowledge. Through the influence of school science, children simultaneously use both scientific and life-world knowledge. Rather than this being an advantage, it brings in more confusion in the scientific community

There is a general observation that if children's ideas are known they could be used to improve the teaching of science. 'The great research effort put into the study of the students conceptions has yielded a vast body of knowledge concerning their conceptions on different scientific topics, which has undoubtedly contributed to improving the way in which science is taught'( Gomez, Bernach and Marin, 2006; p.577).

Mintzes, Trowbridge, Arnaudin \& Wandersee (1991) reported that children's biological ideas should be studied with a perspective to understand those concepts that could impede learning. They contend 'We believe that children's biological concepts are worth studying, not simply as objects of curiosity, but as potential impediments to learners, impediments which, in some cases are remarkably tenacious and resistant to change (p.179). It is argued that when teachers know children's ideas that could impede the learning of scientific concepts; they will then use such ideas to teach science concepts meaningfully.

\section{PURPOSE OF THE STUDY}

The main purpose of this study was to assess children's understanding of plant nutrition. From the main purpose, other purposes also emerged.

(a) To assess children's the level of understanding and misconceptions regarding plant nutrition 
(b) To assess the extent to which children use acceptable scientific language in their answers to free response items on plant nutrition

(c) To compare the performance of boys and girls in both forced and free response items on plant nutrition.

\section{RESEARCH QUESTIONS}

(a) What conceptions and misconceptions about plant nutrition are held by senior secondary school students?

(b) To what extent and under what conditions do students use scientific language in answering free responses items on plant nutrition?

(c) Are there differences between boys' and girls' performance on both free and forced response items on plant nutrition?

\section{RESEARCH HYPOTHESIS}

(a) The performance of boys and girls in plant nutrition is the same as measured by the forced response items

(b) The performance of boys and girls in plant nutrition is the same as measured by the free response items.

(c) Both boys and girls use the same scientific language when answering free response items on plant nutrition.

\section{METHODS}

Following a number of explorations, interviews, a paper and pencil instrument were developed and then administered to 137 students in grade 12 (Form 5), with ages ranging from 15-19. These children were above average in ability. The children involved in this study were randomly selected from a total number of 300 children. The random selection was purposive. The study was carried out in two senior secondary schools in Botswana.

The instrument used for the study was a combination of forced responses (20 multiple choice items) and twelve free response items designed to assess children's understanding of plant nutrition. The development of the instrument was based on the Biology Syllabus for Senior Secondary Schools. The instrument was validated by a professor of science education who confirmed that the instrument indeed assessed children's conceptions of plant nutrition. The instrument was also piloted using 80 Form 5 students who were not part of the study. The test-retest method was used and the instrument's reliability was reported to be at 0.65 . After the admission of the instrument, children's papers were marked. Some children were selected to explain their responses. This was to identify misconceptions that children held about plant nutrition.

There was also a free-response (open-ended) section that required children to respond in written words. The section gave children the opportunity to show their understanding of plant nutrition by expressing themselves in their own words. For example, students were asked to differentiate between micronutrients and macronutrients. The free-response section also gave children the opportunity to present, organize and communicate plant nutrition concepts in the acceptable scientific language. Both forced and free response items covered plant nutrition concepts taught in senior secondary school biology syllabus.

\section{RESULTS}

The findings of the subjects used in this study suggest that they have a weak knowledge and understanding of plant nutrition and are supported by the grand mean of 29 ( out a possible score of 50) for both forced and free response items (Table 1).

Table 1: Mean Scores Of Students For Both Forced And Free Response Items

\begin{tabular}{|c|c|c|}
\hline Gender & Mean & Grand Mean \\
\hline Boys & 29.03 & 29.02 \\
\hline Girls & 29.01 & 2 \\
\hline
\end{tabular}


Use of acceptable scientific language in the free response items was also analyzed under themes as follows.

\section{(a) Definition Of Plant Nutrition}

Boys: "Plant nutrition is the study of nutrients required by plants for growth and survival."

Girls: "Plant nutrient is the study of chemical elements that are necessary for plant growth and development."

\section{(b) Nutrients Requirement}

Boys: "Plants require water, air and sunlight to support photosynthesis."

Girls: "Plants require inorganic materials such as carbon dioxide, water and sunlight to support the process of photosynthesis. Chlorophyll is also required since it is a catalyst in the process of making starches and sugars."

\section{(c) Minerals}

Boys: "They are phosphorus, magnesium and sulphur."

Girls: "They are phosphorus, magnesium and sulphur and must be in ionic forms for them to be absorbed".

Boys: "Potassium and sodium are major salts in plant cells."

Girls: "Potassium and sodium are major salts found in plant cellular fluids."

\section{(d) Making Food}

Boys and Girls: "Plants get their food from soil using roots."

\section{(e) Photosynthesis}

Boys: "Photosynthesis is the process by which plants make sugars and starches using sunlight, water, carbon dioxide and chlorophyll."

Girls: "The process by which green plants (leaves), some bacteria and some organisms using energy from the sun, carbon dioxide, water, chlorophyll to make sugars and starches."

The performance of boys and girls on forced response items is shown in table 2.

Table 2: A Comparison Of Boys' And Girls' Performance On Forced Response Items

\begin{tabular}{|c|c|c|c|c|c|}
\hline Gender & N & Mean & SD & T & P-Vale \\
\hline Boys & 62 & 12,15 & 3.97 & \multirow{2}{*}{0.37} & \multirow{2}{*}{ NS } \\
\hline Girls & 75 & 11.75 & 3.98 & & \\
\hline
\end{tabular}

(The observed or calculated $\mathrm{t}=0.37$ and the critical $\mathrm{t}=1.96$, alpha set at 0.05 )

The performance of boys and girls on free response items is shown in table 3.

Table 3: A Comparison Of Boys' And Girls' Performance On Free Response Items

\begin{tabular}{|c|c|c|c|c|c|}
\hline Gender & N & Mean & SD & T & P-Vale \\
\hline Boys & 62 & 17.4 & 3.97 & \multirow{2}{*}{4.51} & \multirow{2}{*}{0.001} \\
\hline Girls & 75 & 20.48 & 3.98 & & \\
\hline
\end{tabular}

(The observed or calculated $\mathrm{t}=4.51$ and the critical $\mathrm{t}=1.96$, alpha set at 0.05 )

After marking students' responses to forced response items, the author decided to choose four students (two boys and two girls) and asked them to explain why they chose certain options (responses) over others. The purpose 
of asking students to explain their chosen answers to forced response items was to identify misconceptions. The justified responses of children to chosen items are analyzed below.

\section{CHILDREN'S RESPONSES TO SOME FORCED RESPONSE ITEMS}

Researcher: Andrew: Tell me why in Question One, you chose (b) over other options

Andrew: Autotrophic organisms make their own food, but they use inorganic materials to make organic materials, so I realized that (b) was the best option since it talks about synthesizing organic materials from inorganic ones, so it must be correct.

Researcher: Beauty: Explain why in Question One you chose option (d) over other options.

Beauty: I am not sure why I chose (d), but I was attracted by 'they do not require external energy source since they synthesize their own high energy compounds.

Researcher: John, Why did you choose (d) in Question Twelve over other options?

John: I chose (d) over others because there is more salts in the root and therefore less water, I also know that water passes through a plant cell's membranes which are selective and therefore these two points helped me to select (d).

Researcher: Lena, why did you choose (a) in Question 12 over other options?

Lena: Yah, (a) talks of concentration inside and outside the root, um, concentration is usually high inside the root, therefore I choose (a)

Researcher: I would like to thank you all for agreeing to participate in the discussion.

\section{DISCUSSION OF THE RESULTS}

Children used in this study had a weak knowledge and understanding of plant nutrition as reflected by the mean scores of both forced and free response items (table 1). With regards to forced response items, the performance of boys and girls were the same and this suggests that the null hypothesis was tenable. No significance difference was found in performance between boys and girls as measured by the plant nutrition forced response items (see table 2). However, the mean score of boys was slightly higher than that of girls. When students were asked to explain why they chose certain options over others, it was found that the boys were more confident in explaining the options they chose even when the options were wrong. On the other hand, girls were not confident explaining the options they chose. In the free response items, girls performed significantly higher than boys (table 3 ); hence the null hypothesis is rejected (table 3). Girls were found to be very careful in responding to free response items. They used acceptable scientific language than boys. According to Solomon (1993) knowledge is classified into two domains namely, Life-World Knowledge and Scientific Knowledge. Solomon argues that children use Life World Knowledge because it is used in their environment where words have multiple meanings and are negotiated socially. For example, in Life World Knowledge, soil is the source of food for plants. In other words, plants get food from soil. This is a cultural explanation and therefore it is not surprising that students reported that plants get food from soil. Life World Knowledge is inherited from the environment and is passed on to children.

Research reported that the use of loose language by children in biology classes is attributed to the fact that teachers themselves are not strict to children who do not use scientific knowledge (Solomon, 1993). Furthermore, teachers seem not concerned with the use of loose language by students in their answers.

When children answer a scientific question, they first think of the answer in the Life World Knowledge and then later on attempt to explain it using the Scientific Knowledge. 
Solomon (1993) argues that this causes cognitive dissonance. The responses of boys to one of the questions showed use of loose language. Boys reported that plants require phosphorus, sulphur and magnesium, but they did not mention that the minerals are required or absorbed in ionic forms.

According to Solomon (1993), children's developments of scientific concepts are based on life-world knowledge for various reasons.

Solomon mentioned reasons for the use of loose of language in science as follows:

Words used have multiple meanings which are not defined but negotiated socially. Meanings are dependent on the cultural group and on the physical or affective context. Apparent contradictions are tolerated. No logical method is thought to be needed. This knowledge system is well socialized by daily use with examples (p.93)

Solomon emphasizes that teachers should be aware of the coexistence of two domains of knowledge and that Life World knowledge cannot be changed abruptly, teachers should therefore gradually emphasize use of scientific knowledge in their science classes.

\section{CONCLUSION}

In this study, I asked students to justify the options they chose. This was to ensure that students clarify their answers or think seriously about their answers. Research indicates that when students are asked to justify their answers they are able to identify their misconceptions (Smith, 1989). When students explained their understanding of plant nutrition, it was realized that they utilized two modes of explanation, namely Life World Knowledge and Scientific Knowledge. Students using Life World Knowledge to explain plant nutrition concepts based their explanations on knowledge from their environment. When they were probed further, they shifted to scientific knowledge. This caused cognitive dissonance. Those students who used scientific knowledge based their explanations on school science; however, some of their explanations showed lack of conceptual understanding and tended to promote memorization (rote learning). This means they were not able to link what they learned in plant nutrition with anything. McClelland (1989) observes that 'learning is rote if it forms no link with anything but itself, has no ability to help further learning and is learnt by heart' $(p, 136)$

When students justified their responses, they realized why their responses were either right or wrong. This enhanced conceptual learning and equipped children with skills which helped them to talk and think in plant nutrition language. Furthermore it was realized that children learnt science conceptually, were able to link or relate science concepts to everyday life activities.

\section{SUGGESTIONS AND RECOMMENDATIONS}

Plant nutrition is a demanding topic and therefore teachers should use acceptable scientific language when teaching it. Some children were unable to conceptualize food as a product of photosynthesis. Since some words used in plant nutrition are an integral part of our ordinary language, their explanations should not be done loosely. Photosynthesis is not in our Life World Knowledge, we only know that plants get food from soil (heterotrophs). Therefore the concept of autotrophic is difficult to for students to conceptualize.

Since the aim of teaching science is to promote conceptual understanding, different activities could be done to promote conceptual learning.

Since photosynthesis is difficult concept, its understanding could be enhanced by using an analogy (Bread as an analog and photosynthesis as a concept to be learned). 


\begin{tabular}{|l|l|l|}
\hline Processes & Making Bread & Photosynthesis \\
\hline Raw materials & Bread and water & Carbon dioxide from air and water \\
\hline Accessories/Catalysts & Yeast/Baking powder and salt & Chlorophyll \\
\hline Source of Energy & Heat from stove or oven & Sunlight \\
\hline End Products & Bread (Test for starch) & Starch (Test for starch) and oxygen \\
\hline
\end{tabular}

Source: Sloan (1988)

If students do a test for starch, they will be convinced that plants make their own food even though the test for starch in a leaf will show blue green color rather than the expected blue-black color. A normal test for starch in bread will show a blue -black color. This does not happen when testing for proteins.

\section{IMPLICATIONS FOR TEACHING BIOLOGY}

Biology teachers should be aware that students' learning is influenced by two domains of knowledge. In their teaching they must realize that Life World Knowledge predominates children's learning. They must be aware that if Life World Knowledge is used simultaneously with scientific knowledge, this could cause cognitive dissonance/conflicts. However, where Life World Knowledge is not in conflict with scientific knowledge, learning occurs. Teachers should aim at enhancing conceptual understanding for it facilitates storage information in long term memory. Concepts that are leant conceptually tend to be meaning. McClelland (1989) asserts that 'meaningful learning fits into a network of other knowledge, extending both what is already known and what can be learnt' (136).

Teachers should be aware that conceptual learning takes time to be achieved, but so long as students gain knowledge in taking long time teaching a certain concepts, it does not do any harm to continue teaching. Teachers should then find space to teach concepts missed because of time. Teachers should use acceptable scientific language for it is important for students' intellectual growth. If use of scientific language is adopted by teachers, students will emulate the same and will not use loose language in their responses to biological questions that require free responses. Teachers should recognize, interpret students' responses and seriously concentrate on responses that are at variance with conventional science and possibly supplementing them with activities that reinforce conceptual understanding. It has been realized that sometimes secondary school teacher are not comfortable with some biological concepts (e.g. Genetics) and in such situations, it is suggested that team teaching is done in which teachers who are comfortable with the topic would teach it. Teachers should be aware that students' ideas are influenced by their desires to teach for conceptual understanding. If they do not show that desires, they deny students the opportunity that learn science. Secondary school teachers should not only possess strong cone but should also be able to recognize and address students' ideas. It is also recommended that the simplified model of teaching below is used when teaching scientific concepts

\section{REFERENCES}

1. Baxter, J. (1989). Children's understanding of familiar astronomical events. International Journal of Science Education, vo. 11, pp.502=513

2. Bell, B \& Brook, A. (1984). Aspects of secondary students' understanding of plant nutrition. Leeds: University of Leeds, Centre for Studies in Science and mathematics Education.

3. Clement, J., Brown, D.E. \& Zietman, A (1989). Not all preconceptions are misconceptions: finding 'anchoring conceptions' for grounding instruction on students' intuitions. International Journal of Science Education, vol.11, pp.554-565.

4. Driver. R (1989) Students' conceptions and the learning of science. International Journal of science Education. vol.11, pp.481-490.

5. Gomez, E. J., Bernarroch, A. \& Marin, N. 2006). Evaluation of the degree of coherence found in students' conceptions concerning the particulate nature of matter. Journal of Research I Science Teaching, Vol.43. (6). pp. 577-598.

6. Harlen, W (1993). Teaching and learning primary science. $2^{\text {nd }}$ edition London: Paul Chapman 
7. McClleland, J. A. G. (1985). Ausubel's learning theory and its application to introductory science. In B. Hodgson \& E. Scanlon (Eds). Approaching Primary Science (pp. 135-149) London: Harper \& Row

8. Mintzes, J., Trowbridge, J. Arnaudin, M \& Wandersee, J. (1991). Studies on conceptual development in the life sciences. In S. Glynn, R. Yeany and B. Britton (Eds). pp. 179-202). The Psychology of Learning Science. Hillsdale, N.J. Lawrence Erlbaum Associates.

9. Ramorogo, G. J \& Wood-Robinson, C (1995). Batswana children's understanding of biological inheritance. Journal of Biological Education, 29(1), 60-71

10. Republic of Botswana (2000). Botswana General Certificate of Secondary Education Teaching Syllabus: Biology. Gaborone: Curriculum Development and Evaluation, Ministry of Education

11. Resnick, L. B (1983). Mathematics and Science Learning: A New Conception. Science, Vol. 220, pp.477478

12. Sloan, P. (1988). Using research based considerations to develop a science textbook unit about photosynthesis. Unpublished manuscript, University of Georgia. Athens, GA

13. Smith, E.L. (1989). A conceptual science model for teaching science. In S. Glynn, R. Yeany and B. Britton (Eds.), pp. 179-202). The Psychology of Learning Science. Hillsdale, N.J. Lawrence Erlbaum Associates.

14. Solomon, J. (1993).The social construction of children's scientific knowledge. In P.J. Black \&A.M. Lucas (Eds.), (pp.85-101). Children's Informal Ideas in Science. London: Routledge.

15. Wandersee, J.H., Mintzes, J.J. \& Novak, J. D (1994). Research on alternative conceptions in science. In. D.L. Gabel (Ed). Handbook of Research on Science Teaching and Learning (pp.177-210). New York: Macmillan 


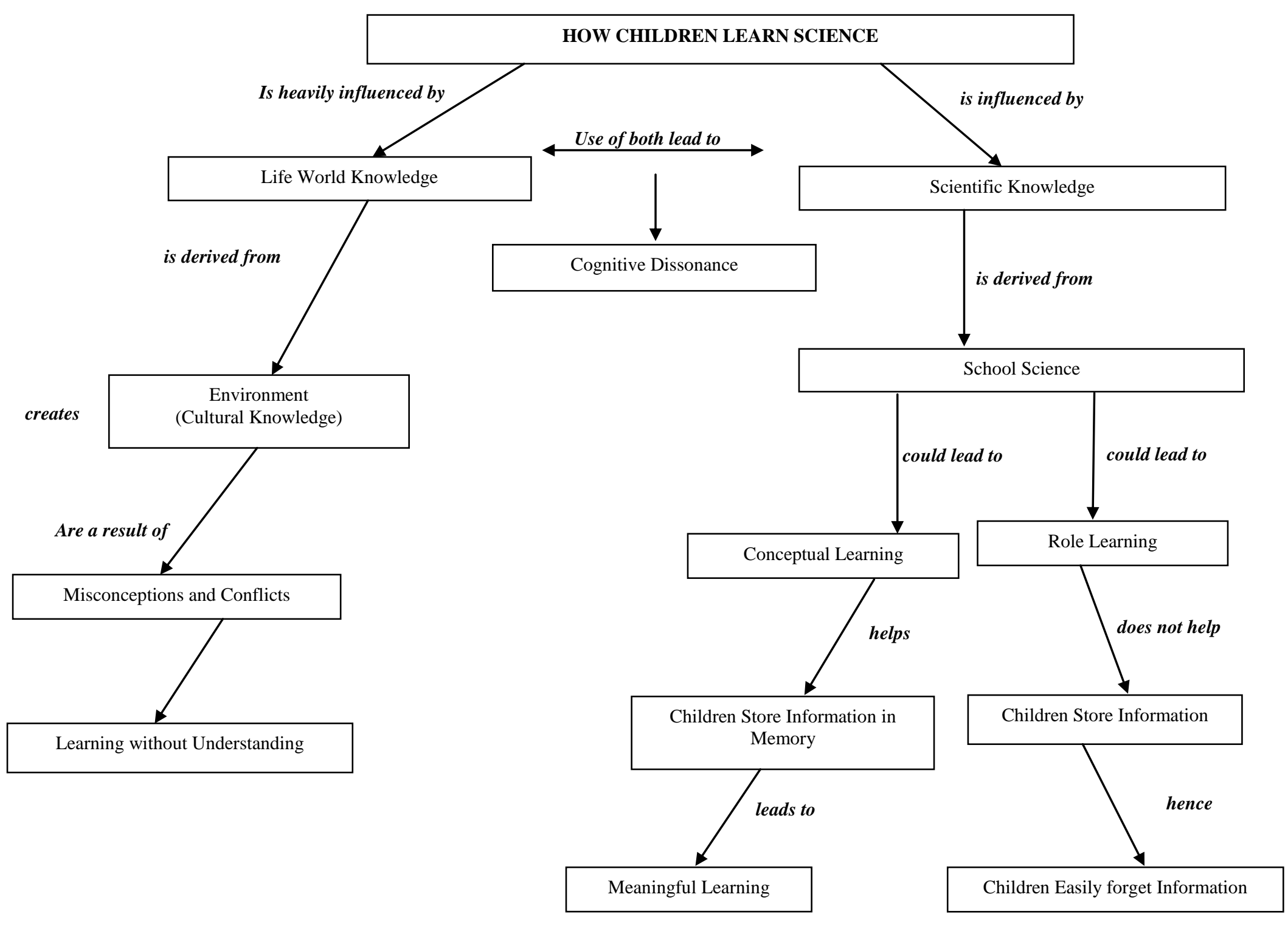

